\title{
In Vitro Rumen Fermentation Characteristics and Microbes of Thin Tail Sheep Given Sweet Potato Biomass
}

\author{
Sudarman $\mathrm{A}^{1}$, Hayashida $\mathrm{M}^{2}$, Miralestari $\mathrm{M}^{1}$ \\ ${ }^{I}$ Department of Nutrition and Feed Technology, Faculty of Animal Science, \\ Bogor Agricultural University, Bogor 16680, Indonesia \\ ${ }^{2}$ Department of Bioproduction Technology, Junior College \\ Tokyo University of Agriculture, Japan \\ E-mail: a_sudarman@yahoo.com \\ (received 28-04-2016; revised 17-05-2016; accepted 09-06-2016)
}

\begin{abstract}
ABSTRAK
Sudarman A, Hayashida M, Miralestari M. 2016. Karakteristik rumen fermentasi secara in vitro dan mikroba domba ekor tipis yang diberikan biomassa ubi jalar. JITV 21(2): 83-87. DOI: http://dx.doi.org/10.14334/jitv.v21i2.1355

Tanaman ubi jalar (Ipomoea batatas L) diproduksi di Indonesia dalam jumlah besar. Daun dan batang ubi jalar dapat digunakan sebagai sumber protein dan umbinya dapat digunakan sebagai sumber energi. Penelitian ini bertujuan untuk mengkaji pengaruh pemberian biomasa ubi jalar pada karakteristik fermentasi rumen, kecernaan bahan kering dan bahan organic, serta populasi mikroba rumen domba ekor tipis. Penelitian ini menggunakan rancangan acak kelompok dengan menerapkan empat perlakuan pakan, yaitu, T0 (100\% rumput gajah), T1 (70\% dari rumput gajah $+30 \%$ konsentrat), T2 (50\% dari rumput gajah + $50 \%$ daun ubi jalar), dan T3 (70\% daun ubi jalar $+30 \%$ umbi ubi jalar) dengan tiga ulangan. Sampel cairan rumen diambil dengan metode stomach tube dengan menggunakan pompa vakum. Hasil penelitian menunjukkan bahwa perlakuan T3 memiliki kecernaan bahan kering dan bahan organik, konsentrasi NH3 dan VFA, dan populasi bakteri rumen lebih tinggi $(\mathrm{P}<0,05)$ daripada perlakuan T0 dan T1 tetapi tidak berbeda dengan perlakuan T2. Populasi protozoa dan pH rumen tidak berbeda antar perlakuan. Dapat disimpulkan bahwa penggunaan biomassa ubi jalar dapat meningkatkan kualitas fermentasi rumen domba.
\end{abstract}

Kata Kunci: Rumen, Kecernaan, Fermentasi, Domba, Biomassa Ubi Jalar

\section{ABSTRACT}

Sudarman A, Hayashida M, Miralestari M. 2016. In vitro rumen fermentation characteristics and microbes of thin tail sheep given sweet potato biomass. JITV 21(2): 83-87. DOI: http://dx.doi.org/10.14334/jitv.v21i2.1355

Sweet potato plant (Ipomoea batatas L) is produced in Indonesia in large quantities. Sweet potato leaves and stems can be used as a source of protein and the tuber can be used as an energy source. This study was aimed to analyze the effect of feeding of sweet potato biomass on the rumen fermentation characteristics, digestibility of dry matter and organic matter as well as rumen microbial population of thin tail sheep. This study used a randomized block design by applying four feed treatments, i.e., T0 (100\% Napier grass), T1 (70\% of Napier grass $+30 \%$ concentrate), T2 (50\% of Napier grass $+50 \%$ sweet potato leaves), and T3 (70\% sweet potato leaves $+30 \%$ sweet potato tuber) with three replicates. Rumen fluid samples were taken with stomach tube method using a vacuum pump. Results showed that the $\mathrm{T} 3$ diet has higher $(\mathrm{P}<0.05)$ digestibility of dry matter and organic matter, concentration of $\mathrm{NH}_{3}$ and VFA, and rumen bacterial population than those of $\mathrm{T} 0$ and T1diets but similar to that of T2 diet. Rumen $\mathrm{pH}$ and protozoa population was not different among the treatments. It can be concluded that the use of sweet potato biomass can improve the quality of rumen fermentation of sheep.

Key Words: Rumen, Digestibility, Fermentation, Sheep, Sweet Potato Biomass

\section{INTRODUCTION}

Low quality and fluctuated availability of feed may lead to low productivity of sheep. Most small holder farmers feed their sheep only by field grass regardless adequacy of the nutrients and nutrition required by sheep.

By-product of agriculture or plantations overflowing around the sheep farms may be used as an alternative good quality and cheap price feed. In Bogor, for example, are widely grown sweet potatoes producing waste that can be utilized by small holder farmers to feed their sheep. Sweet potato is widely grown by farmers because its relatively easy processing, have relatively short harvest period and resistant to drought.

In 2014, production of sweet potato in Indonesia amounted to 2,382,025 tonnes, while in West Java amounted to 471,737 tonnes and in Bogor amounted to 82,935 tonnes (CSA 2015). Sweet potato vines may be used as protein feed source containing $19.38 \%$ crude protein and $3720 \mathrm{Kcal} / \mathrm{kg}$ energy (Kebede et al. 2008), whereas the tubers can be used as an energy source with 
energy content of $4156 \mathrm{Kcal} / \mathrm{kg}$ and crude protein content of 5.5\% (Heuzé et al. 2015).

Results of previous studies show that the addition of sweet potato crops in napier grass-based diets may improve rate of degradation by rumen microbes and rumen fermentation which increases feed intake and animal productivity (Kariuki et al. 2001). This in vitro study was aimed to analyze effect of giving biomass sweet potato (Ipomoea batatas L.) on rumen fermentation characteristics and microbial rumen of sheep.

\section{MATERIALS AND METHODS}

Napier grass, sweet potato leaves, and sweet potato tubers flour were previously prepared by drying them for 2-3 days and then finely grounded. Concentrate were made by mixing coconut meal $30 \%$, wheat pollard $15.29 \%$, peanut meal $25 \%$, cassava waste flour $27.08 \%$, $\mathrm{CaCO}_{3} 1.93 \%$, salt $0.2 \%$, and premix $0.5 \%$. Treatment diets were T0: $100 \%$ grass, $\mathrm{T} 1=70 \%$ of Napier grass + $30 \%$ concentrate, $\mathrm{T} 2=50 \%$ Napier grass $+50 \%$ potato leaves, $\mathrm{T} 3=70 \%$ leaf $+30 \%$ potato tubers. Nutrient content and composition of the treatments used are presented in Table 1.

Approximately $15-20 \mathrm{ml}$ of rumen liquor were collected from three sheep before morning meal using a stomach tube with vaccum pump. Samples were filtered and analysed for protozoa and bacteria (Ogimoto \& Imai 1981), ammonia concentration (Conway 1962), total volatile fatty acids (VFAs) using steam distillation method (GLP 1966), dry matter and organic matter digestibility (Tilley \& Terry 1963), and rumen $\mathrm{pH}$. Experimental design was based on a randomized complete block design using four treatments as describes above with three blocks for each treatment.
The blocks were based on three sheep that had been taken their rumen fluid. Data were analyzed using analysis of variance (ANOVA) (Steel \& Torrie 1993). Any significant differences $(\mathrm{P}<0.05)$ of mean were further tested using Duncan's multiple range test. All statistical analysis were performed using SPSS software version 16.0.

\section{RESULTS AND DISCUSSION}

\section{Rumen fermentation characteristics}

Results on rumen fermentation characteristic variables were presented in Table 2. Those three treatments had no significant $(\mathrm{P}>0.05)$ effect on rumen $\mathrm{pH}$. Rumen $\mathrm{pH}$ value has an important role in supporting rumen microbial growth. Proper rumen microbial growth leads to normal fermentation process producing VFA and $\mathrm{NH}_{3}$ (Uhi et al. 2006). Rumen $\mathrm{pH}$ values in this study were in normal range around neutral, i.e., 6.93-7.00.

Those treatments significantly $(\mathrm{P}<0.05)$ affected VFA concentration. VFA value in treatment $\mathrm{T} 3(70 \%$ leaves and stems of sweet potatoes $+30 \%$ sweet potato tubers) did not differ from T2 treatment but was higher than the T1 and T0 treatment (Table 2). This is because of $\mathrm{T} 3$ treatment contained the highest NFE in the ration $(58.91 \%)$ derived from feed energy source use, namely, sweet potato tubers. On the other hand due to the relatively low content of NFE in the ration (47.42\%), T0 treatment had the lowest VFA concentration compared with other treatments (Table 2). NFE is an easily digestible carbohydrate that can be used as an energy source for livestock (Farida \& Ridwan 2011). Easily digestible carbohydrates are in group of

Table 1. Chemical composition (\% DM basis) of experimental diets

\begin{tabular}{lcccc}
\hline \hline \multirow{2}{*}{ Nutrient } & \multicolumn{3}{c}{ Treatment diets* } \\
\cline { 2 - 5 } & T0 & T1 & T2 & T3 \\
\hline Dry matter (DM) & 21.56 & 42.017 & 18.025 & 18.444 \\
Crude protein (CP) & 7.97 & 8.879 & 13.195 & 13.662 \\
Ether extract (EE) & 5.1 & 5.755 & 6.345 & 5.571 \\
Crude fibre (CF) & 26.9 & 22.001 & 21.28 & 11.841 \\
Nitrogen free extract (NFE) & 47.42 & 50.24 & 46.705 & 58.911 \\
Ash & 12.61 & 13.123 & 12.72 & 10.358 \\
TDN** & 54.97 & 58.207 & 62.29 & 74.161 \\
\hline
\end{tabular}

Results of laboratory analyzes of Research Center for Biological Resources and Biotechnology of IPB (2015)

$* *$ Result of the calculation according to Hartadi et al. (1997)

$* \mathrm{~T} 0=100 \%$ Napier grass

$\mathrm{T} 1=70 \%$ Napier grass $+30 \%$ concentrate

$\mathrm{T} 2=50 \%$ Napier grass $+50 \%$ sweet potato leaves

$\mathrm{T} 3=70 \%$ sweet potato leaves $+30 \%$ sweat potato tuber 
Table 2. Effect of treatment on the rumen fermentation characteristics

\begin{tabular}{lcccc}
\hline \hline \multirow{2}{*}{ Parameters } & \multicolumn{4}{c}{ Treatment diets* } \\
\cline { 2 - 5 } & $\mathrm{T} 0$ & $\mathrm{~T} 1$ & $\mathrm{~T} 2$ & $\mathrm{~T} 3$ \\
\hline $\mathrm{pH}$ & $6.97 \pm 0.06$ & $7.00 \pm 0.00$ & $6.93 \pm 0.06$ & $7.00 \pm 0.00$ \\
$\mathrm{VFA}(\mathrm{mM})$ & $99.94 \pm 6.46^{\mathrm{c}}$ & $107.42 \pm 6.90^{\mathrm{bc}}$ & $116.39 \pm 11.69^{\mathrm{ab}}$ & $125.27 \pm 6.77^{\mathrm{a}}$ \\
$\mathrm{NH}_{3}(\mathrm{mM})$ & $6.89 \pm 0.44^{\mathrm{c}}$ & $7.80 \pm 1.30^{\mathrm{bc}}$ & $9.01 \pm 1.53^{\mathrm{ab}}$ & $10.41 \pm 1.42^{\mathrm{a}}$ \\
IVDMD (\%) & $45.23 \pm 3.92^{\mathrm{c}}$ & $47.90 \pm 1.88^{\mathrm{c}}$ & $62.50 \pm 1.39^{\mathrm{b}}$ & $72.29 \pm 4.60^{\mathrm{a}}$ \\
IVOMD (\%) & $40.25 \pm 5.95^{\mathrm{c}}$ & $45.81 \pm 1.69^{\mathrm{c}}$ & $61.55 \pm 1.88^{\mathrm{b}}$ & $72.10 \pm 5.58^{\mathrm{a}}$ \\
\hline
\end{tabular}

$* \mathrm{~T} 0=100 \%$ Napier grass

$\mathrm{T} 1=70 \%$ Napier grass $+30 \%$ concentrate

$\mathrm{T} 2=50 \%$ Napier grass $+50 \%$ sweet potato leaves

$\mathrm{T} 3=70 \%$ sweet potato leaves $+30 \%$ sweat potato tuber

Different superscript within the same row shows significant $(\mathrm{P}<0.05)$ difference

polysaccharide starch. Starch in rumen will be hydrolyzed into monosaccharide by rumen microbial enzymes and further fermented into VFA such as acetate, propionate, and butyrate, and gases of $\mathrm{CH}_{4}$ and $\mathrm{CO}_{2}$. Total VFA concentration in this study was slightly lower than that of the finding of Puastuti et al. (2012) that was 122.5-190.3 mM. VFA production of a feedstuff reflects its fermentability level. VFA produced was higher along with higher fermentability level of a feedstuff.

Those three treatment also had a significant effect $(\mathrm{P}<0.05)$ on the concentration of $\mathrm{NH}_{3}$. Concentration of $\mathrm{NH}_{3}$ result had the same pattern as the VFA result. Concentration of $\mathrm{NH}_{3}$ in treatment $\mathrm{T} 3(70 \%$ leaves and stems of sweet potatoes $+30 \%$ sweet potato tubers) did not differ from that of $\mathrm{T} 2$, but was higher than those of $\mathrm{T} 1$ and $\mathrm{T} 0$ treatments (Table 2). This figure caused by protein content in rations T3 was the highest (13.66\%) compared to other treatments (Table 1). Feed protein undergoes hydrolyisis into oligopeptide by proteolytic enzymes. Oligopeptides were then undergo deamination and converted into an amino acid producing $\mathrm{NH}_{3}$. High crude protein content in feed will produce high $\mathrm{NH}_{3}$. Concentration of ammonia in the rumen depends on protein content of feed. Quality of protein in the diet may also affect the concentration of ammonia. Large quantities of low quality protein would not be beneficial, because most of the protein would be degraded by rumen microbes into ammonia. Excess of ammonia will be discarded through urine causing low efficiency of protein utilization. T0 treatment contained the lowest crude protein $(7.97 \%)$, therefore produced the lowest $\mathrm{NH}_{3}$ concentration compared to other treatments. $\mathrm{NH}_{3}$ concentration of all treatments in this study were comparable with the results of Puastuti et al. (2012) showing that $\mathrm{NH}_{3}$ concentration of sheep fed napier grass and supplemented with rumen undegradable protein ranged from 7.4 to $9.4 \mathrm{mM}$.

\section{Digestibility of dry matter and organic matter}

Those three treatments significantly $(\mathrm{P}<0.01)$ affected digestibility of dry matter and organic matter. Digestibility of dry matter and organic matter of T3 treatment $(70 \%$ leaves and stems of sweet potatoes + $30 \%$ sweet potato tubers) was the highest compared to those T0, T1 and T2 treatment. Digestibility value of feeds was in contrast to their crude fibre content. The lower crude fiber content, the higher digestibility value of feed. Crude fibre content of T3 treatment was the lowest followed by treatment of $\mathrm{T} 2$, T1, and T0, i.e., $11.8 \%, 21.3 \%, 22.0 \%$ and $26.9 \%$, respectively. Results were in line with the results of Aregheore (2004) showing that sweet potato had digestibility more than $62 \%$.

Digestibility value of $\mathrm{T} 1$ treatment was not significantly different from the digestibility value of T0 treatment (Table 2). This clearly shows that the addition of $30 \%$ concentrate on the treatment $\mathrm{T} 1$ could not increase digestibility value of feed. Digestibility value in T0 treatment (fed only grass) was the lowest compared to that of other treatments (Table 2). It was caused by the high crude fiber content of elephant grass in the T0 ration, i.e., $26.9 \%$, where the crude fiber is a component that is difficult to be digested.

\section{Rumen microbial population}

Population of ruminal bacteria and protozoa in this study were presented in Table 3 . High number of bacterial populations on $\mathrm{T} 3$ treatment was followed by increase of concentration of VFA and $\mathrm{NH}_{3}$. This indicates that bacteria on the T3 treatment were capable in utilizing VFA and ammonia from feed degradation for their growth. In turn, it produces more bacterial population that may accelerate fermentation process of feed. So that, VFA and NH3 results will also increase. 
Table 3. Effect of treatment on the rumen microbial population

\begin{tabular}{|c|c|c|c|c|}
\hline \multirow{2}{*}{ Parameters } & \multicolumn{4}{|c|}{ Treatment diets* } \\
\hline & T0 & $\mathrm{T} 1$ & $\mathrm{~T} 2$ & $\mathrm{~T} 3$ \\
\hline Bacteria (Log CFU ml ${ }^{-1}$ ) & $8.29 \pm 0.02^{\mathrm{c}}$ & $8.35 \pm 0.01^{\mathrm{b}}$ & $8.37 \pm 0.04^{\mathrm{ab}}$ & $8.42 \pm 0.02^{\mathrm{a}}$ \\
\hline Protozoa $\left(\right.$ Log cell $\left.\mathrm{ml}^{-1}\right)$ & $6.39 \pm 0.09$ & $6.36 \pm 0.09$ & $6.35 \pm 0.10$ & $6.30 \pm 0.09$ \\
\hline
\end{tabular}

The results was supported by Siwaporn et al. (2010) who reported that in cattle producing high VFA and in buffalo producing high $\mathrm{N}-\mathrm{NH}_{3}$, the ruminal bacteria population was high. Increase of VFA amount may be caused by the presence of amylolytic and cellulolytic bacterial population that is capable to degrade fiber and starch in feed into VFA. Bacterial population of T0 (100\% grass) was the lowest compared to that of the other treatments. This may be due to the protozoa populations of $\mathrm{T} 0$ treatment tend to be highest. It is well known that high population of protozoa may prey on population of cellulolytic and amylolytic bacteria. As a consequent, the VFA produced is low. The present results proved that low population of bacteria of the T0 treatment was accompanied by the low concentration of the VFA. Protozoa population in T3 treatment tended to be lower, so that T3 treatment bacterial population increased. In the T3 treatment, sweet potato leaves with its saponin content (Anthoney \& Omwenga 2014) was able to lysis protozoa cell causing them to death, but saponin had no effect on bacterial cells.

Total bacteria in this experiment $\left(19.50 \times 10^{7} / \mathrm{ml}\right.$ $\left.26.30 \times 10^{7} / \mathrm{ml}\right)$ were lower that reported by Singh \& Kundu (2011) $\left(8.53 \times 10^{8} / \mathrm{ml}-16.05 \times 10^{8} / \mathrm{ml}\right)$ for the sheep fed by Dicanthium annulatum grass based diet and supplemented with Leucaena leucocephala and Hardwickia binata. This discrepancy probably due to that many of bacteria in this experiment were eaten by protozoa, as shown by the number of protozoa in this study was higher than the protozoa reported by Singh \& Kundu (2011).

The treatments did not significantly $(\mathrm{P}>0.05)$ affect protozoa population (Table 3). T2 and T3 treatments containing sweet potato leaves tended to have lower protozoa population than $\mathrm{T} 0$ and $\mathrm{T} 1$. There was a tendency showing that with increasing level of sweet potato leves, the protozoa population increased. This may indicate that sweet potato leaves have an anti protozoa agent. Eventhough the effect was not so strong. Sweet potato plant is known to contain anti- nutrients of saponin (Anthoney \& Omwenga 2014). Saponin usually used as defaunating agents being capable to lysis protozoa cell (Wang et al. 2011). Thus higher sweet potato leaves given produces higher saponin content in the feed that is able to lysis protozoa cell in greater numbers. Sweet potato leaves contain saponin (Pochapski et al. 2011) as defaunating agent being capable in reducing protozoa population. Protozoa population of the T0 (100\% elephant grass) and $\mathrm{T} 1$ (70\% of elephant grass $+30 \%$ concentrate) tended to be higher than that of T2 and T3 treatments. $\mathrm{T} 0$ and T1 treatmnets did not use sweet potato leaves, so it did not contain saponin that may reduce population of protozoa. Lower rumen protozoa populations of sheep were reported by Singh \& Kundu (2011) as 5.34 and $3.95 \times 10^{5} / \mathrm{ml}$ in rumen of sheep fed by Dicanthium annulatum grass based diet and supplemented with Leucaena leucocephala and Hardwickia binata in 75:25 ratio, respectively. Lower protozoa population of Singh \& Kundu (2011) than that in this study probably due to that Leucaena leucocephala and Hardwickia binata had higher secondary compound (condensed tannin and saponin) that capable in reducing protozoa population.

\section{CONCLUSION}

Use of sweet potato biomass may improve quality of ruminal fermentation of sheep. Providing of $30 \%$ tubers and $70 \%$ leaves (T3 diet) of sweet potato afeected dry and organic matters digestibility concentration of $\mathrm{NH}_{3}$ and VFA as well as bacterial population were higher than other treatments. Moreover, it had no siginificant effect on protozoa population.

\section{ACKNOWLEDGEMENT}

Authors wish to thank "International Cooperative Research Project (TUA-IPB-MSU)" of Tokyo University of Agriculture for the financial support. 


\section{REFERENCES}

Anthoney ST, Omwenga J. 2014. Analysis of phytochemical composition of white and purple sweet potato (Ipomoea batatas L.). J Adv Plant Res. 1:19-22.

Aregheore EM. 2004. Nutritive value of sweet potato (Ipomoea batatas L.) forage as goat feed: voluntary intake, growth and digestibility of mixed rations of sweet potato and batiki grass (Ischaemum aristatum var. indicum). Small Rumin Res. 51:235-241.

[CSA] Central Statistic Agency. 2015. Statistik Indonesia 2015. Jakarta (Indones): Central Statistic Agency.

Conway EJ. 1962. Micro-diffusion analysis and volumetric error. 5th ed. London (UK): Crosby Lockwood \& Sons Ltd.

Farida WR, Ridwan R. 2011. Giving of formulated pellet on Javan Porcupine (Hystrix javanica F. Cuvier, 1823): Effects on feed intake, feed conversion, and digestibility in pre-domestication condition. J Bio Indones. 7:157170.

[GLP] General Laboratory Procedures. 1966. Department of Dairy Science. Madison (USA): University of Wisconsin.

Hartadi HS, Reksohadiprodjo, Tillman AD. 1997. Tabel komposisi pakan untuk Indonesia. Yogyakarta (Indonesia): Gadjah Mada University Press.

Heuzé V, Tran G, Hassoun P, Renaudeau D, Bastianelli D. 2015. Sweet potato (Ipomoea batatas) tubers. Feedipedia, a programme by INRA, CIRAD, AFZ and FAO. [accessed September 7th 2016]. http://www.feedipedia.org/node/745.

Kariuki JN, Tamminga S, Gachuiri CK, Gitau GH, Muia JMK. 2001. Intake and rumen degradation in cattle fed Napier grass (Pennisetum purpureum) supplemented with various levels of Desmodium intortum and Ipomoea batatas L. vines. J Anim Sci. 31:149-157.

Kebede T, Lemma T, Tadesse E, Guru M. 2008. Effect of level of substitution of sweet potato (Ipomea batatas $\mathrm{L}$ ) vines for concentrate on body weight gain and carcass characteristics of browsing Arsi-Bale goats. J Cell Anim Bio. 2:036-042.

Pochapski MT, Fosquiera EC, Esmerino LA, dos Santos EB, Farago PV, Santos FA, Groppo FC. 2011. Phytochemical screening, antioxidant, and antimicrobial activities of the crude leaves' extract from Ipomoea batatas (L.) Lam. Pharmacogn Mag. 7:165-170. doi: 10.4103/0973-1296.80682.

Siwaporn P, Wanapat M, Wachirapakorn C, Nontaso N. 2010. The effect of roughage and urea solution infusion levels on ruminal NH3-N concentration and nutrient digestibility in beef cattle and swamp buffaloes. Silpakorn U Sci Technol J. 4:47-55.

Ogimoto K, Imai S. 1981. Atlas of rumen microbiology. Tokyo (Japan): Japan Scientific Societes Press.

Puastuti W, Yulistiani D, Mathius I-W. 2012. Ruminal fermentation response and nitrogen retention from sheep fed rumen undegradable protein. Indones J Anim Vet Sci. 17:67-72.

Singh S, Kundu SS. 2011. Comparative rumen microbial population in sheep fed Dicantium annulatum grass supplemented with Leucaena leucocephala and Hardwickia binate tree leaves. Livest Res Rural Develop. Vol. 23. Article \#7. http://www.lrrd.org/lrrd23/1/ sing 23007.htm.

Steel RGD, Torrie JH. 1993. Prinsip dan prosedur statistika. Edisi Ke-3. Terjemahan. Jakarta (Indones): PT Gramedia.

Tilley JMA, Terry RA. 1963. A two-stage technique for the in vitro digestion of forage crops. J Br Grassl Soc. 18:104111.

Uhi HT, Parakkasi A, Haryanto B. 2006. Pengaruh suplemen katalitik terhadap karakteristik dan populasi mikroba rumen domba. J Anim Sci Technol. 29:20-26.

Wang JK, Ye JA, Jian-Xin L. 2011. Effects of tea saponins on rumen microbiota, rumen fermentation, methane production and growth performance. Trop Anim Health Prod. 44:697-706. 